DE DE GRUYTER

OPEN

DOI: 10.1515/aa-2015-0003

\title{
The deficit myth of our culture. Confirming the Sacred
}

\section{Otilia Sîrbu}

In 2001 Otilia Sirbu received a PhD. degree in philology from the Faculty of Letters, University of Bucharest. Currently she is a lecturer at the Faculty of Letters and Foreign Languages, University of Hyperion, Bucharest. Her current research interests include: the history of Romanian literature, mythocritique, imagology, contemporary French literature, and the history of theatre.

\begin{abstract}
The term sacred can define itself by the influence it has. It can also be quantified simply by reporting it to other realities such as the profane, the mysterious, the absolute, the infinite and even the possible. From this analogy, the most successful, most imposing collocation is the one made from the sacred and the profane. The opposition between the two underlines two realities, giving the former a rightful and expected brilliance, and the latter the well-defined role it has taken upon itself.
\end{abstract}

The term sacred is as alive in all religions on Earth as it is in the Semitic religions; in Latin, Greek and other ancient languages, it determines first and foremost a surplus - a surplus that can be identified with a unique emotion we carry; it is not solely about relating to morality , in the biblical religions especially. The latter give it the name qādosh, to which correspond hagios and sanctus or, to be precise, sacer. The words imply the idea of "good" in all three languages - absolute "good". However, the Latin term "sacer" is translated as sacred or cursed, therefore combining the harmful with the beneficial. In his "vocabulary" (Le Vocabulaire des institutions indo-européenes, 1969) E. Benvéniste states that all IndoEuropean languages retain complementary terms to define the term sacred. Despite the absence of exact corresponding terms, two tendencies can be identified, namely:

- on the one hand, these languages define a supernatural, transcending force that becomes the identity of the divine: spneta avestic, hails gotic, hiéros grecesc (reserved only for the gods or inspired by them, unlike hosios, which is permitted to humans by the gods);

- on the other hand, we find terms that designate the idea of holiness as a consequence of an act of separation, protected by a law: yaozdata avestic (which can designate a religious process), Greek hagios and Latin sanctus, both indicating that the object is protected from any exterior interference. However, this comparison would not be whole if we did not take the percentage given to the possible, in its universal acceptance, into consideration, as well as the absolute, the infinite, nonexistence but also existence. The contradiction stands between the two terms, sacred and profane: the world, with its two sides, defined by an irreparable contradiction. However, after close analysis, the boundary between sacred and profane is revealed to be highly delicate: a good enough reason to explain ignoring, but also infringement of a boundary that was only right to be known. Everything that is religious is sacred, everything that is related to sacred implies religion. Everything that is profane is not accepted in the temple but left outside in the street. Through this, things are divided from the start. In reality, the difference between a sacred, ritualistic gesture and a profane one is far 
from being this clear. Sacred living is a balance that is difficult to maintain between contrary aspirations that are, however, always mixed. The opposition between profane and sacred is no more definitive as the one between work and play se one can play while also being productive and work while in a relaxed and detached state of mind (Wunenburger, 2000, p. 85). For Mircea Eliade this contradiction seems simpler: "...the only activities that are not 'sacred' are the ones that have no mythological significance, those that lack an example worth imitating" (Eliade, 2011, p. 34). In general we use a certain analysis, the invasion of the sacred by the profane, of the everyday onto the existential surplus that is sacred, without outlining the full presence of the sacred in the simplest of human activity. It is worth mentioning how much influence one has on the other. The sacred invades our everyday lives, but in certain amounts and for a specific purpose. It tries to give a fluidity, a coherence and endow us with that "gift", bringing us back to our origin which once was sacred. Take, for instance, dancing. All forms of dancing were originally sacred; in other words, they had a non-human model (...). What we are interested in is its supposed non-human origins (for all forms of dancing in illo tempore, in mythical times, by some "ancostor", a totem animal, a god or a hero. Its choreographic rhythms have their origins outside man's profane life; whether they reproduce the moves of a totem or emblematic animal, or even those of the heavenly bodies; whether they are rituals on their own (labyrinthine steps, leaps, gestures performed with the help of ceremonial tools etc.) dances always mimic an archetype gesture or honour a mythical event. In a word they are a repetition and, as a result, a revival of that ,certain time” (Eliade, 2011, p. 45). What is significant about the separation between the sacred and the profane is in fact the power the sacred has, which man feels, knows instinctively and carries within. "The sacred has a specific power which gives it a quality that the profane lacks" (Ries, 2000, p. 45). Furthermore, contact with the sacred constitutes the "dynamics of religions, their syncretism and reforms" (Ries, 2000, p. 45).

\section{Modern man vs. Homo religious}

Modern man is a traveller in his own world. His own forgotten, abandoned world that has been updated over and over, a world often dishonest even with him. His state of abandonment, remnants of the day that passed, meeting the darkness, his lack of performance as a human being is almost lost forever. Modern man is poor, despite his material wealth. He hides in poverty, in a sea of anxiety, hoping it is only superficial. His faith as fleeting as is presence in his life. How many causes are there for this drama? One cause could be religion. Because the more pressure is put on propagating religion, the more it will confuse contemporary man, the more he will "suffer from his own weakness." This situation is unfair because man is the starting point (and always has been) in the course of experiencing the religious. If ancient and medieval man lacked the ability to represent an infinite temporal space, contemporary man has achieved it, has encountered it and, when he began, "declared" himself homo religiosus: a man of the beginning of beginnings who lived his own existences in the cosmos, whose behaviour and way of thinking intertwined by experiencing the sacred. Homo religiosus believed in the sacred, it was his own divine aspect. He lived his own adventure of life and did not fail to preserve it through prayers, myths and rituals, leaving them as an inheritance through cave paintings, stone and wood carvings, leather, papyrus or parchment. Homo religiosus was no longer alone. He was accompanied by homo symbolicus who not only spoke of his religious experience but also initiated and made it a fundamental part of his life. He increased the number of markings and symbols and defines his own existence along with them: "Regardless of the historical context he belongs to, homo symbolicus always believes that the sacred is an absolute reality that transcends this world in which he manifests himself and this is why he deifies it and makes it real." (Eliade, 1965, p. 171).Contemporary man has the same convictions regarding the existence of the sacred, with 
the distinction that the sacred is now different in his eyes. It is the same reality but seen from the point of view of the permanently useful in his book "The end of modern", Romano Guardini states that contemporary man, the man of the present and so called modern, no longer sees the world as a shelter. "The modern world enjoys justifying technical measures with the usefulness they bring to man's wellbeing. Through this it hides the ravages its negligence caused." (Guardini, 2004, p. 66). Even its technical and scientific reasoning, the belief of human accomplishment by "approaching it" only make returning to the sacred become useless. As complex as humanity has become, it has shown over time to have lost its depth. How much of homo religiosus has contemporary man lost?

\section{Homo religious}

Homo religiosus is one that believes in absolute reality, which is defined by his notion of the sacred. The universe stands between the two, the cosmos trapped in its important, unmoving and unchanging data. The life of this person, unquestioning of his cosmic destiny, is accompanied by another, natural man, as Rudolf Otto defined him. Therefore, if one is "complete" and the other natural, how can the two be compared to one another? What does one lack that the other has? If the sacred, as religious historians believe, manifests itself and appears before man, then why is it not accessible to everyone? What special data is implied when meeting the sacred? What does homo religiosus have that the "other" lacks, because religious experience has the same space-time positions in M. Eliade's theory: "The act of speaking remains the same: manifesting the sacred through something different than itself; the sacred appears in objects, myths or symbols, but never completely and in its immediate integrity." (Eliade, 1992, p. 35). Therefore the sacred is in everything. However, something that makes it "accessible" to "homo religiosus". Whose merit is it, who approaches who or what in this encounter? The sacred is so overwhelmingly manifested that it "strikes" the one that assists or the other, who knows how to "see" it and welcome it. In this encounter "something" completely different appears in this transcending reality: the sacred being, all that surrounds it and sacred objects receive more than his natural energy. The hierophany is perceived by the religious man, he being a religious phenomenon. He is inseparable from human experience - the religious human experience. The three elements, hierophany, the religious man and his way of life define a whole. Any hierophany consists of three elements. The natural object, the invisible reality and the mediating object imbued by the sacred. Of all these elements, the only one that remains in its place is the being and the objects that surround it. They are static, surrounded by an invisible reality, the second term of hierophany. This reality has different names but each of them significant: "the transcending world" or "the world of the gods" or "the world above" etc. Whatever linguistic mantle it gains, it is nothing other than an absolute, sacred, transcending reality. It is in fact Eliade's sacred; it is God; it is Absolute; it is Guenon's possible; it is Otto's numinous and it is our holiness. The third element, the mediator, is the one that becomes something else, that gains a new dimension, a sacred one, whether it is a being or an object that represents it. It becomes sacredness. What is amazing is the fact that, although the sacred is unlimited, in the given situation it accepts being limited. Through the object that it coveys its data to, it accepts the finite. A limit of the sacred it imposes on itself. From the Moon's symbolism to that of the Sun, in the search for the human of today, I oppose the modern world with its tortured, devilish side. I oppose the dementia that grinds its otherwise natural state. I declare that I am not part of this world in too much of a hurry, though I willingly submit to its rhythm. I fall into a burning trap of constant searching, but also my own search for essence. I am divided into two sides, the burning but also the magical. I wish I was impartial though I admit I often am not. Because of the hurried rhythm I let myself be preoccupied with the essential, searching to see and rediscover humanity's genuine humility, the path to happiness that is so highly praised, which is 
temporarily closed. I forget then, as I do now, about the constantly busy modern day and declare myself happy, if only for a second.

That was yesterday.

Today I am doing something else. I am attempting to fix things and understand them. But how?

It is well known, now more than ever because it is a world dominated by the media, engrossed in technology and space exploration, that there are people who live in pristine surroundings, dominated by a pure, timeless energy, experiencing the greatness of the human condition. Ordinary or dull at first sight, upon closer attention we see that the truth is far from being so simple. What gives these simple people, headstrong in their actions, their faith, their unaltered behaviour, so certain of their own happiness? How can they afford to be the true ones? Is it the way they want to be or is it their only option? What is the source of happiness? What embodies it? What makes it called the way it is? These questions are posed today, what of tomorrow... For a better understanding of the two realities, of the burning modern day and the magical one, I have selected two reference points, the Sun and the Moon. At first glance, the Moon is the symbol of night and the Sun is the symbol of day. However, in reality, things are more different and vast. The Moon is a celestial body that has a remarkable influence on Earth's organic life. It is well known how people used to calculate time in the past. In IndoEuropean terminology, the term "moon" is the oldest term refering to a celestial body. Its root is me, which in Sanskrit became mami and can be translated as "I measure". Using that linguistic reality, we can say that the Moon is a measure of time and, as a result, of people on Earth. There are many revealing examples: the likeness between a woman's fertility and that of the Earth, the nine months of the prenatal phase related to the nine nights of lunar ascension with the nine nights of full moon, the three days of mourning after the disappearance of someone on Earth, related to the three days of the moon covered in darkness that later revives itself, the sight of life after death. Therefore the Moon accompanies our life, our ascension but also our stagnation. As a reward it was praised, written of in poetry and prose, embraced by those in love and adored by the nostalgic. The Moon received everything, rewarding us in full. I do not know when we lost the luxury of our "lunar" friendship. Today's man enjoys the presence of the Moon the same as our ancestors. Only now he no longer bows to it even though he is subject to its rhythm. He, modern man, has chosen another celestial body: the Sun. The question is: so what? What connections are there between the Sun, Moon and human happiness? Going back to the Moon, as M. Eliade says in his book 'Euthanasius' Island", the Moon's role is so much more overwhelming for the human conscience that it is understood not only as a unit of measure but also as a "bridge between very different realities" (Eliade, 2008):

"It is easy to understand why the primitive man, le moins-civilisé, considered the Moon more important (at least in certain sages of culture) than the Sun. The Sun is a heavenly body that man cannot relate to in any way: it is eternal, equal to itself, without any form of "becoming". The Moon, however, is an orb that grows, shrinks and disappears; a heavenly body whose life is bound by the same laws of growing, being born and dying. The Moon's "life" is thus closer to man's than the glorious, majestic life of the Sun. and since the beginning of agriculture in the Neolithic period, man linked the lunar stages with Earth's fertility. The Moon brings rain; it is the universal symbol of fertility. Now the first cosmic symbols are made clear, the true thought process that unites different levels: the Moon, the Woman, the Earth, fertility. From this Man has a united "concept" of the Cosmos, his intuition encompasses Everything but not an abstract everything, gained from dialect, but a living, rhythmic, dramatic Everything. This central intuition is the foundation of magic, which has origins in the Paleolithic" (Eliade, 2008, p.82). 
I will not start from a current theory, the theory of the present or humanity's permanent theory according to which happiness is only a fulfilment. Happiness can be fulfilment under one condition: if the journey to achieve it is authentic. If we transform this search for happiness into an ideal, all we do is minimise our own human potential. And out of our desire to save it I search for other means, once walked and now forgotten. Pascal Bruckner presents the idea that by constantly turning happiness into an ultimate ideal it was turned into a means to intimidate, a terrifying challenge to which we all fall victim (Lipovetsky, p. 295). Confusing the present, I head for the Moon's dimension, to what it "grants" us. The abundance of lunar symbolism shows how great a role the first intuitions of the cosmos had, all these contribute to the development of the human mind: "Vast and great mental syntheses were made under the mark of the moon, compared to them, the attempts of the pre-Socratic minds to create a "unity of the world" seem humble and unworthy. Birth, conception, death; the moon, the water, the woman; the growth of the moon, the plants, man; death as a palingenesis, a moment in the cosmic rhythm, death as a repose (returning to darkness, to earth, to the prenatal); darkness, sadness, drought, "evil"; light, rain (the light cast by the lightning that brings rain is the same as moonlight) richness of vegetation, "good"; the world below, the world above, rebirth, etc. there are just a few from the list of mental syntheses created around the moon. We have to linger on their united, synthetic character. The conscience that created them truly had a seamless intuition of the Cosmos; it did not go step by step, going from emblem to emblem as we do today when deciphering such primordial symbols" (Eliade, 2008).

Paraphrasing Eliade, I could add that today not only do we not know how to decipher these symbols but we are not even aware of them anymore. We ignore them in an obviously devastating way for our souls. We have lost touch with our natural rhythms, imposed upon us by divinity, the cosmos and the moon. Out of too much desperation we have adapted to another celestial body: the Sun. I will not list its natural aspects: light, warmth. I will speak of its burning and unchanging aspect. It is an unchanging whole. Daily, or almost daily, we are divided between the burning day-to-day way of life and the magical one. We are torn between the two, helpless, fixed in our stagnant state, just like the solar celestial body. And at night, under the Moon's glimmering rays, if we are fortunate enough to remember it, the people of today become the people of before. Our lone wolf howl is the howl of sadness. We have left the path to happiness, to ourselves. Even my example seems unhappy but is not. We are alone in the universe, escaping the hand of God; we put our faith in science, in the art of technology that creates happiness. Then we are lost; we have forgotten nature, the natural rhythm, our partner the Moon seems alone in its ascent and stagnation of humans.

What could save us from the constriction of eternal loneliness, of unhappiness is only the summer solstice in the middle of the day. Then and only then can we return to the beginning of time, the time of our eternal authenticity, our only path to happiness. 


\section{Works cited:}

Eliade, M. 2011. Mitul eternei reîntoarceri. Editura Univers Enciclopedic Gold: București. Eliade, M.1992. Istoria Credințelorși ideilor religioase. Editura Universitas: Chișinău. Guardini, R. 2004. Sfârșitul modernității. Editura Humanitas: București.

Lipovetsky, G. 2007. Fericirea paradoxală. Trans. Mihai Ungurea. Editura Polirom: Iași. Ries, J. 2000. Sacrul în istoria religioasă a omenirii. Editura Polirom: Iași.

Wunenburger, J-J. 2000. Sacrul. Editura Dacia: Cluj-Napoca.

\section{Otilia Sirbu}

Department of Letters and Foreign Languages,

Faculty of Social Sciences, Humanities and Nature,

University Hyperion of Bucharest

Romania

Otilia.sirbu@gmail.com 